\title{
PERIODE PEMBERIAN PAKAN YANG MENGANDUNG KITIN UNTUK MEMACU PERTUMBUHAN DAN PRODUKSI IKAN GURAMI Osphronemus gouramy (LACEPEDE)
}

\author{
Wiadnya, D.G.R.', Hartati Kartikaningsih"), Yanti Suryanti"), Subagyo"', \\ dan Anik M. Hariati
}

\begin{abstract}
ABSTRAK
Penelitian tentang waktu pemberian pakan yang mengandung kitin terhadap pertumbuhan dan produksi ikan gurami telah dilakukan di kolam percobaan. Tujuan percobaan adalah untuk mengetahui periode waktu yang tepat dalam pemberian pakan mengandung kitin untuk menghasilkan pertumbuhan dan produksi optimal ikan gurami. Percobaan dilakukan pada 15 unit kolam beton, dengan luas masing-masing $32 \mathrm{~m}^{2}$, dan kedalaman air $\pm 90 \mathrm{~cm}$. Pada masingmasing kolam ditebar benih ikan gurami ukuran rata-rata $3,5 \mathrm{~g}$ dengan kepadatan $25 \mathrm{ekor} / \mathrm{m}^{2}$ atau 800 ekor/kolam. Jenis pakan pellet F1 dan F2 dibuat iso-protein dan iso-energi, namun pakan F2 ditambah unsur kitin $\pm 8,0 \%$. Penelitian dilakukan selama empat bulan dengan perlakuan periode waktu pemberian pakan pelet yang mengandung kitin. Periode waktunya adalah $0,1,2$, 3 , dan 4 bulan. Jumlah pemberian pakan pelet adalah 3,0\% bobot biomassa per hari, diberikan pagi dan sore hari. Hasil percobaan menunjukkan bahwa periode pemberian pelet yang mengandung kitin lebih dari dua bulan dapat meningkatkan laju pertumbuhan harian, produksi dan retensi nutrien ikan gurami. Dengan meningkatnya periode pemberian pakan yang mengandung kitin maka laju pertumbuhan dan produksi biomassa juga meningkat secara linier.
\end{abstract}

ABSTRACT: Feeding period of diet containing chitin to accelerate growth and production in giant gouramy, Osphronemus gouramy (Lacepede). By: Wiadnya, D.G.R., H.Kartikaningsih, Y. Suryanti, Subagyo, dan A.M. Hariati.

An experiment on feeding strategy of feed containing chitin on giant gouramy fry was carried out in ponds. The research aimed to determine optimum feeding period of diet containing chitin (resulted from waste of shrimp processing industry), in order to increase growth and optimal production of giant gouramy. The investigation was conducted in 15 concrete ponds (32 $\mathrm{m}^{2}$ each). Every pond was stocked with 800 individuals of giant gouramy fry of 3.5 g/individual. Two pelleted feeds (F1 and F2) were formulated at iso-protein and iso-energi content, with F2 containing $\pm 8,0 \%$ chitin and F1 without chitin. The treatment were: 0, 1, 2, 3, and 4 months feeding period. The pelleted feed was given twice a day at $3.0 \%$ of estimated biomass. Every month sampling was held to estimate individual body weight and to adjust the feed amount. The result showed that feed cointaining chitin $\pm 8,0 \%$ given more than two months period increased daily growth rate (SGR), production and retention nutrien of giant gouramy. Increasing the period of feed containing chitin (F2) increased the growth rate and linier biomass production.

KEYWORDS: chitin, gouramy, feed, growth rate

\section{PENDAHULUAN}

Salah satu kendala dalam budi daya ikan gurami adalah pertumbuhannya yang relatif lambat. Untuk mencapai ukuran konsumsi 500-700 g/ekor, petani membutuhkan waktu budi daya sekitar 24 bulan. Pertumbuhan ikan gurami tersebut secara relatif jauh lebih lambat dibandingkan spesies ikan air tawar lainnya, seperti ikan mas, nila, maupun lele (Ardiwinata, 1971; Kartikaningsih et al., 1997; Jauhari, 1996). Lambatnya pertumbuhan ikan gurami ini diduga disebabkan oleh dua faktor utama yaitu: a. Kondisi internal ikan (faktor genetik) sehubungan dengan kemampuan ikan dalam mencerna dan memanfaatkan pakan sebagai deposit dalam bentuk pertambahan bobot tubuh

b. Kondisi eksternal pakan, yang formulasinya belum mengandung sumber nutrien yang lengkap bagi ikan sehingga tidak bisa memacu pertumbuhan pada tingkat optimal.

Kitin adalah polimer rantai panjang dari polisakarida yang tersusun atas molekul-molekul gula sederhana berbentuk kristal dan berwarna putih (Putro,

\footnotetext{
Pengajar pada Universitas Brawijaya, Malang

${ }^{\star \star}$ ) Peneliti pada Balai Penelitian Perikanan Air Tawar
} 
1982). Clark et al. (1973) menambahkan bahwa kitin merupakan polimer (tak bercabang) dari N-asetil-Dglukosamin (NAG), terdapat pada eksoskeleton, saluran pencernaan dan membran peritropik pada sebagian besar spesies krustase. Bahan ini, di dalam tubuh udang terutama berasal dari organisme yang dimakannya. Kitin bisa didapat dengan memanfaatkan limbah pembekuan udang. Menurut Hong (1985), rendeman kitin yang diperoleh dari cangkang atau eksoskeleton udang mencapai $23,5 \%$ bobot kering. Bastaman (1989) menyatakan bahwa ekstraksi kitin dari kulit udang dapat dilakukan melalui proses deproteinasi dan demineralisasi

Sumber pakan yang mengandung glukosamin (monomer glukosa dalam kitin) dapat berfungsi sebagai growth-promoting factor atau pemacu pertumbuhan pada udang. Hal ini terjadi terutama karena percepatan pertumbuhan dan metabolisme karbohidrat pada udang (Kanazawa et al., 1970 Kitabayashi et al., 1971; Clark et al., 1993; Fox, 1993) Selanjutnya Clark et al. (1993) menambahkan bahwa kitin antara $1 \%-4 \%$ pada sumber pakan akan meningkatkan daya cerna dan memacu pertumbuhan. Hal ini memberikan indikasi tentang kemampuan udang untuk menyerap dan menggunakan sumber pakan dari glukosamin. Secara analog, glukosamin dari sumber kitin diharapkan juga mampu memacu pertumbuhan jenis organisme akuatik lainnya, terutama untuk ikan gurami, sehingga pertumbuhan gurami yang relatif lambat dapat dipacu. Jika hipotesis ini bisa dibuktikan maka hambatan pada budi daya ikan gurami diharapkan bisa dipecahkan dan periode budi daya bisa dipercepat untuk menghasilkan ikan konsumsi.

Kitin sebagai hasil ekstrak dari limbah pengolahan udang diduga bisa dimanfaatkan untuk mempercepat pertumbuhan ikan gurami. Berdasarkan hasil penelitian Kartikaningsih et al. (1997), penambahan kitin ke dalam pakan ikan dapat mempengaruhi respon pertumbuhan dan efisiensi pemanfaatan pakannya. Penambahan kitin ke dalam pakan sebesar $8,0 \%$ menghasilkan pertumbuhan dan pemanfaatan pakan lebih tinggi. Hal ini bisa dilakukan melalui pencernaan karbohidrat, sehingga protein lebih banyak tersimpan pada tubuh ikan dalam bentuk cadangan energi pertumbuhan. Percobaan ini bertujuan untuk mengetahui periode waktu yang tepat dalam pemberian kitin sebagai sumber pakan sehingga menghasilkan pertumbuhan ikan gurami yang optimal.

\section{BAHAN DAN METODE}

Ekstraksi kitin, pembuatan pakan berbentuk pelet dan analisis proksimatnya dilakukan di Laboratorium Unibraw, sedangkan untuk uji respon pertumbuhan ikan gurami dilakukan di Kolam Percobaan Budi daya
Fakultas Perikanan Universitas Brawijaya, Malang Percobaan dilakukan pada bulan Agustus sampai bulan Desember 1997. Komposisi pakan pelet yang digunakan dalam percobaan ini mengandung 35,0\% protein; $12 \%$ lemak; dan $41,0 \%$ karbohidrat, dengan kandungan energi $3,5 \mathrm{kkal} / \mathrm{g}$ dan $\mathrm{kitin} 8 \%$.

Percobaan dilakukan pada 15 kolam beton, masing-masing berukuran $4 \times 8 \mathrm{~m}^{2}$ (kedalaman \pm 90 $\mathrm{cm}$ ). Masing-masing kolam ditebar ikan gurami dengan kepadatan 25 ekor $/ \mathrm{m}^{2}$ sehingga setiap kolam ditebar 800 ekor benih berukuran rata-rata 3,5 g per ekor. Rancangan Acak Lengkap digunakan dalam percobaan ini. Sebagai perlakuan adalah waktu pemberian pakan mengandung kitin $8 \%$ selama 0,1 , 2, 3, dan 4 bulan. Di luar waktu percobaan, ikan diberi pakan baku tanpa kitin. Setiap perlakuan diulang tiga kali. Jumlah pakan yang diberikan 3,0\% dari perkiraan biomassa per hari, yang diberikan dua kali, pada pagi dan sore hari. Setiap bulan dilakukan sampling. Sampling 100 ekor ikan dilakukan dengan menggunakan jaring halus (mesh) $0,5 \mathrm{~cm}$. Bobot rata-rata individu dihitung dari pengukuran bobot biomassa ikan dalam sampel (100 ekor) dibagi dengan jumlah ikan dalam sampel. Penimbangan biomassa ikan dilakukan dengan timbangan elektrik (ketelitian 0,1 g). Pada akhir penelitian dilakukan pemanenan seluruh ikan dari masing-masing kolam dan penimbangan biomassa serta penghitungan jumlah total ikan yang masih hidup

Variabel yang dianalisis dari data hasil pengamatan adalah laju pertumbuhan harian (DGR), konversi pakan (FCR), retensi nutrien (protein, lemak dan energi), sintasan (SR), dan biomassa produksi panen (B). Laju pertumbuhan harian (DGR) dihitung dengan persamaan:

$$
D G R=\frac{\ln W_{t}-\ln W_{0}}{t} \times 100, \quad(\% B W / \text { hari }) \%
$$

Konversi pakan:

$$
F C R=\frac{F}{W_{t}-W_{o}} ; \quad(g / g)
$$

Retensi nutrien (protein lemak dan energi)

$$
R_{\text {nutrien }}=\frac{N_{o}}{N_{t}} \times 100 ;
$$

Sintasan (SR)

$$
S R=\frac{N_{t}}{N_{0}} \times 100
$$

sedangkan biomassa produksi akhir adalah

$$
B=B_{t}-B_{0} \quad\left(g / m^{2}\right)
$$


dengan

$\mathrm{W}_{0}=$ Bobot individu ikan pada awal penelitian $(\mathrm{g})$

$\mathrm{Wt}=$ Bobot individu ikan pada akhir penelitian $(\mathrm{g})$

$\mathrm{F} \quad=$ Jumlah akumulasi pakan yang diberikan $(\mathrm{kg})$ selama penelitian

$\mathrm{N}=$ Jumlah deposit nutrien pada tubuh ikan selama penelitian

$\mathrm{N}=$ = Jumlah nutrien yang diberikan dalam penelitian

$\mathrm{N}_{0} \quad=$ Jumlah ikan yang ditebar pada awal penelitian (800 ekor/ kolam)

$\mathrm{N} \quad=$ Jumlah ikan yang hidup sampai pada akhir penelitian

$B_{0}=$ Biomassa total ikan yang ditebar pada awal penelitian $\left(\mathrm{g} / \mathrm{m}^{2}\right)$

$\mathrm{B}_{1}=$ Biomassa total ikan yang didapat pada akhir penelitian $\left(\mathrm{g} / \mathrm{m}^{2}\right)$

$\mathrm{BW}=$ Bobot tubuh

Setiap hari dilakukan pengukuran kualitas air, masing-masing pada pagi (06.00 WIB) dan sore hari (18.00 WIB). Parameter kualitas air yang diukur adalah oksigen terlarut (DO), suhu air, $\mathrm{pH}$ air, kecerahan, dan kedalaman air pada masing-masing kolam. Oksigen terlarut dan suhu air diukur dengan alat DOmeter, $\mathrm{pH}$ diukur dengan $\mathrm{pH}-\mathrm{pen}$, sedangkan kecerahan air diukur dengan piring (secchi disk). Kedalaman kolam bisa dilihat dari petunjuk meteran yang tertera pada dinding beton masing-masing kolam.

Setiap bulan juga dilakukan pengukuran kekeruhan air dan indeks klorofil. Kekeruhan air diukur dengan alat Turbidity-meter (TEF), sedangkan indeks klorofil diukur dengan ekstraksi klorofil dalam larutan aceton $80 \%$, yang selanjutnya ditera pada spektrofotometer (alat HACH-DR2000).

Analisis sidik ragam (Snedecor \& Cochran, 1991), dilakukan terhadap variabel pertumbuhan harian (DGR), konversi pakan (FCR), sintasan (SR), retensi nutrien $(R)$, dan biomassa produksi $(B)$. Jika dalam analisis sidik ragam di antara perlakuan berbeda nyata dilakukan uji beda nyata terkecil (Snededcor \& Cochran, 1991). Semua prosedur pengolahan data menggunakan paket program SX. 35 (Statistik, 1985).

Untuk mengetahui respon antara periode waktu pemberian pakan yang mengandung kitin terhadap laju pertumbuhan dan variabel lainnya, dilakukan analisis regresi dan kurva-linier (Snedecor \& Cochran, 1991).

\section{HASIL DAN BAHASAN}

Hasil analisis ragam dan BNT terhadap variabel SR, DGR, FCR, dan produksi disajikan pada Tabel 1. Perbedaan perlakuan periode waktu pemberian pakan yang mengandung kitin menyebabkan seluruh variabel berbeda nyata $(P \leq 0,05)$, kecuali terhadap sintasan $(S R)$ yang tidak berbeda nyata $(P \geq 0,05)$. Nilai pertumbuhan harian (DGR) tertinggi dicapai pada perlakuan pemberian pakan kitin selama empat bulan yang mencapai $2,61 \%$. Sedangkan nilai terendah didapat pada perlakuan kontrol (0) dan satu bulan pemberian pakan berkitin.

Penambahan kitin $8 \%$ pada pakan dapat meningkatkan laju pertumbuhan harian ikan gurami jika pakan tersebut diberikan dalam periode lebih dari dua bulan, karena pada periode pemberian antara 1-2 bulan laju pertumbuhan masih belum berbeda (Tabel 1). Dengan pemberian kitin dalam pakan, laju pertumbuhan harian bisa ditingkatkan 0,58\% BW/hari. Dalam hal ini karena kitin dapat meningkatkan daya cerna pakan pada ikan gurami, pemanfaatan pakan untuk deposit energi dalam tubuh menjadi lebih tinggi (Clark et al., 1993; Fox, 1993).

Tabel 1. Sintasan, laju pertumbuhan harian, konversi pakan, dan bobot biomassa (B) ikan gurami. Table 1. Survival rate (SR), daily growth rate $(D G R)$, feed conversion ratio (FCR) and biomass weight (B) of gouramy.

\begin{tabular}{ccccc}
\hline $\begin{array}{c}\text { Perlakuan (bulan) } \\
\text { Treatment (month) }\end{array}$ & SR & DGR & FCR & B \\
\hline 0 & $87.46 \pm 7.18^{\mathrm{a}}$ & $2.03 \pm 0.00^{\mathrm{a}}$ & $2.58 \pm 0.11^{\mathrm{a}}$ & $802 \pm 69^{\mathrm{a}}$ \\
1 & $80.75 \pm 3.76^{\mathrm{a}}$ & $2.11 \pm 0.01^{\mathrm{a}}$ & $2.67 \pm 0.12^{\mathrm{a}}$ & $825 \pm 60^{\mathrm{a}}$ \\
2 & $82.29 \pm 5.39^{\mathrm{a}}$ & $2.35 \pm 0.07^{\mathrm{b}}$ & $2.04 \pm 0.29^{\mathrm{b}}$ & $1.147 \pm 39^{\mathrm{b}}$ \\
3 & $93.92 \pm 6.07^{\mathrm{a}}$ & $2.50 \pm 0.05^{\mathrm{c}}$ & $1.97 \pm 0.17^{\mathrm{b}}$ & $1,426 \pm 211^{\mathrm{c}}$ \\
4 & $89.42 \pm 6.83^{\mathrm{a}}$ & $2.61 \pm 0.06^{\mathrm{d}}$ & $1.85 \pm 0.27^{\mathrm{b}}$ & $1,744 \pm 25^{\mathrm{d}}$ \\
\hline
\end{tabular}

$\mathrm{SR} \quad=$ sintasan (survival rate)

DGR = laju pertumbuhan harian (daily growth rate)

FCR = konversi pakan (feed conversion ratio)

$\mathrm{B} \quad=$ biomassa produksi panen (harvest biomass product)

* Angka dalam kolom yang diikuti dengan huruf yang sama tidak berbeda nyata (Values in the same column followed with the same superscript are not significantly different $)(P>0.05)$ 
Hubungan antara laju pertumbuhan harian dengan periode lamanya pemberian kitin, membentuk kurva linier dengan persamaan:

$$
Y=2,01+0,18 X ; r=0,97 ; d b=13
$$

Pemberian pakan berkitin antara kontrol ( 0 bulan) dan satu bulan tidak berbeda $(P>0,05)$ dalam hal konversi pakan, sedangkan pada perlakuan 2, 3, dan 4 bulan berbeda nyata $(P<0,05)$ dengan perlakuan kontrol ( 0 bulan) dan satu bulan (Tabel 1). Rendahnya konversi pakan ini diduga karena tingginya daya cerna pakan tersebut sehingga pemanfaatan pakan oleh tubuh menjadi lebih efisien.

Nilai sintasan hasil percobaan ini bervariasi antara 80\%-90\%. Hal ini relatif sama dengan hasil penelitian Insan et al., (1993 dan 1994), yaitu bahwa ikan gurami yang dipelihara di kolam akan mempunyai variasi sintasan antara 80\%-90\%. Mortalitas pada ikan gurami bisa disebabkan oleh serangan bakteri, jamur serta kemungkinan defisiensi vitamin C (Ardiwinata, 1971). Hasil pengamatan terhadap ikan yang mati selama penelitian tidak memberikan indikasi yang jelas terjadinya serangan penyakit. Ikan yang mati tidak memperlihatkan adanya kerusakan organ secara morfologis akibat serangan jamur maupun bakteri, serta tanda-tanda lainnya. Ikan-ikan yang mati biasanya mengambang pada permukaan air setelah 24 jam. Sedangkan ikan yang sakit bisa dilihat dari matanya yang relatif besar dan membengkak, sirip geripis, dan bagian tubuh yang membengkok.

Pertambahan biomassa produksi tertinggi didapat pada perlakuan pemberian pakan dengan kandungan kitin selama empat bulan. Peningkatan biomassa terjadi dengan semakin lamanya periode pemberian pakan yang mengandung kitin. Sedangkan pada periode pemberian pakan selama satu bulan, respon pertambahan biomassa masih belum berbeda nyata
$(P>0,05)$. Pertambahan biomassa produksi ikan gurami berhubungan langsung dengan periode pemberian pakan yang mengandung kitin dengan persamaan:

$$
Y=692,12+48,5 X ; r=0,95 ; d b=13
$$

dengan

$Y=$ pertambahan biomassa ikan gurami ( $\mathrm{g} / \mathrm{m}^{2} / 4$ bulan) $X=$ periode pemberian pakan kitin (bulan)

Nilai biomassa produksi ikan gurami pada percobaan ada hubungannya dengan pertumbuhan dan konversi pakan. Pada prinsipnya, pertumbuhan ikan gurami bisa dipacu sampai batas tertentu dengan meningkatkan daya cerna atau penambahan bahan tertentu (Kusdiarti et al., 1994; Kartikaningsih et al. 1997). Penambahan enzim kompleks lebih dari $2 \%$ dalam pakan pelet akan meningkatkan pertumbuhan dan biomassa produksi ikan gurami (Insan et al. 1992). Selain enżim, pengkayaan pakan pelet dengan bahan tanaman Azolla (Insan et al., 1994) juga dapat meningkatkan pertumbuhan ikan gurami

Retensi protein menunjukkan kemampuan ikan untuk memanfaatkan protein pakan ke dalam tubuh ikan. Hasil analisis ragam terhadap retensi protein menunjukkan perbedaan nyata antar perlakuan $(P<0,05)$ dan semakin lama waktu pemberian kitin semakin besar retensi proteinnya (Tabel 2). Retensi protein tertinggi diperoleh pada perlakuan pemberian kitin selama empat bulan.

Retensi protein mengalami peningkatan dengan meningkatnya periode pemberian pakan kitin, dengan persamaan:

$$
R_{\text {protein }}=20,54+2,34 X ; \quad r=0,77 ; d b=3
$$

Sedangkan hubungan antara retensi lemak berdasarkan periode pemberian pakan kitin adalah linier. Retensi lemak mengalami peningkatan dengan

Tabel 2. Nilai rata-rata dan standar deviasi setiap perlakuan untuk retensi protein, lemak, dan energi.

Table 2. Average value and standard deviation of each treatment for protein, fat, and energy retention.

\begin{tabular}{cccc}
$\begin{array}{c}\text { Perlakuan (bulan) } \\
\text { Treatment (month) }\end{array}$ & $\begin{array}{c}\text { Retensi Protein } \\
\text { Protein Retention }\end{array}$ & $\begin{array}{c}\text { Retensi Lemak } \\
\text { Fat Retention }\end{array}$ & $\begin{array}{c}\text { Retensi Energi } \\
\text { Energy Retention }\end{array}$ \\
\hline 0 & $21.35 \pm 1.08 \mathrm{a}$ & $18.13 \pm 0.96^{\mathrm{a}}$ & $15.96 \pm 1.03^{\mathrm{a}}$ \\
1 & $20.66 \pm 0.70^{\mathrm{ab}}$ & $17.95 \pm 0.51^{\mathrm{a}}$ & $15.98 \pm 1.08^{\mathrm{a}}$ \\
2 & $26.32 \pm 3.88^{\mathrm{c}}$ & $23.90 \pm 3.94^{\mathrm{b}}$ & $20.54 \pm 2.51^{\mathrm{b}}$ \\
3 & $28.75 \pm 2.33^{\mathrm{c}}$ & $26.89 \pm 2.44^{\mathrm{b}}$ & $21.24 \pm 2.09^{\mathrm{b}}$ \\
4 & $29.01 \pm 4.69^{\mathrm{c}}$ & $27.84 \pm 4.88^{\mathrm{b}}$ & $22.40 \pm 4.75^{\mathrm{b}}$
\end{tabular}

Angka dalam kolom yang sama diikuti huruf superskrip yang sama tidak berbeda nyata (Values in the same column followed with the same superscript are not significantly different) $(P>0,05)$ 
Tabel 3. Nilai kualitas air selama percobaan.

Table 3. Value of water quality during the experiment

\begin{tabular}{lc}
\hline \multicolumn{1}{c}{$\begin{array}{c}\text { Parameter } \\
\text { Parameter }\end{array}$} & $\begin{array}{c}\text { Kisaran } \\
\text { Range }\end{array}$ \\
\hline Oksigen terlarut (Dissolved oxygen) $(\mathrm{mg} / \mathrm{L})$ & $5.48-7.71$ \\
Suhu (Temperature) $\left({ }^{\circ} \mathrm{C}\right)$ & $24.95-25.12$ \\
$\mathrm{pH}$ & $7.52-7.65$ \\
Kecerahan (Turbidity) $(\mathrm{cm})$ & $42.08-45.00$ \\
Indeks klorofil (Chlorophil index) & $94.43-122.21$ \\
\hline
\end{tabular}

meningkatnya periode pemberian pakan kitin, dengan persamaan;

$$
R_{\text {lemak }}=17,27+2,84 X ; \quad r=0,82 ; d b=13
$$

Retensi lemak dan protein dalam tubuh ikan gurami ini merupakan komponen utama dalam penyusunan retensi energi. Pemberian pakan yang mengandung kitin (8\%) meningkatkan retensi energi dalam tubuh, sesuai dengan peningkatan retensi kandungan lemak, dengan persamaan:

$$
R_{\text {energi }}=15,6+1,81 X ; r=0,74 ; d b=13
$$

Kemampuan penyerapan lemak ada hubungannya dengan struktur enzim kompleks yang bisa diberikan melalui pakan untuk meningkatkan daya cerna pakan. Pemberian enzim papain (Yuniarti, 1998; Herlinawati, 1998; Widayati, 1998; Abida, 1998) juga dapat meningkatkan penyerapan nutrien, sehingga retensi energi meningkat

Hasil pengamatan terhadap parameter kualitas air di antara perlakuan tidak menunjukkan perbedaan. Data kualitas air masih dalam kisaran yang baik untuk pemeliharaan gurami (Tabel 3).

\section{KESIMPULAN}

1. Pakan pelet yang mengandung bahan kitin murni $8,0 \%$ dapat meningkatkan laju pertumbuhan harian ikan gurami, Osphronemus gouramy (Lacepede) bila diberikan lebih dari dua bulan.

2. Dengan meningkatnya periode pemberian kitin maka laju pertumbuhan dan produksi biomassa juga meningkat secara linier.

3. Campuran kitin pada pakan dapat meningkatkan efisiensi pencernaan pakan pelet yang diberikan pada ikan gurami.

4. Retensi nutrien (protein, lemak, dan energi) pada ikan gurami meningkat dengan peningkatan periode pemberian pakan pelet yang mengandung 8,0\% kitin. Retensi lemak lebih tinggi dibandingkan dengan retensi protein

\section{UCAPAN TERIMA KASIH}

Tim Peneliti menyampaikan terima kasih kepada Agricultural Research Management Project (ARMPII) dan Direktorat Jenderal Pendidikan Tinggi (DIKTI) Departemen Pendidikan dan Kebudayaan yang telah memberikan kesempatan dan dana untuk melaksanakan penelitian ini.

\section{DAFTAR PUSTAKA}

Abida, I.W. 1998. Pengaruh Pemberian Ekstrak Daun Pepaya, Carica papaya Linn. dalam Ransum Pakan Ikan Lele terhadap Daya Cerna Nutrien Ikan Gurami, Osphronemus gouramy Lac. Skripsi Fakultas Perikanan Univ. Brawidjaya, Malang. 74 pp

Ardiwinata, R.O. 1971. Fish culture. III. The culture of Giant Gouramy. Sumur Bandung Press. Bandung $87 \mathrm{pp}$.

Bastaman, S. 1989. Studies on Degradation and Extraction of Chitin and Chitosan from Prawn Shells. M.Sc thesis. Queen's Univ. of Belafast, UK. 134 pp.

Clark, D.J., Kawrence, A.L., and Swakon, D.H.D. 1993 Apparent chitin digestibility in penaeid shirmp Aquaculture 109: 51-57.

Fox, C.J. 1993. The effect of shrimp dietary chitin on growth, survival and chitinase levels in the digestive gland of juvenile Penaeus monodon. Aquaculture 109: $39-49$

Herlinawati, Y. 1998. Pengaruh Pemberian Enzim Papain dalam Ransum Pakan Ikan terhadap Respon Pertumbuhan Ikan Gurami (Osphronemous gouramy Lac.). Skripsi Fakultas Perikanan Univ Brawidjaya, Malang. 73 pp

Hong, N.K. 1985. Isolation and characterization of chitin from crawfish shell waste. Journal Agriculture and Food Chemistry. Vol 37: 3 .

Insan I., Wahyudi, N.A., dan Kusdiarti. 1995. Penggunaan azolla sebagai pengganti pakan buatan dalam usaha pendederan ikan gurami. Prosiding Seminar Hasil Penelitian Perikanan Air Tawar 1993/1994. Balai Penelitian Perikanan Air Tawar, Sukamandi. p. 289295.

Insan I., Kusdiarti, dan Subamia, I.W. 1994. Pengaruh penambahan enzim komplek terhadap kecernaan 
pakan dan pertumbuhan ikan gurami (Osphronemous gouramy). Prosiding Seminar Hasil Penelitian Perikanan Air Tawar 1992/1993. Balai Penelitian Perikanan Air Tawar, Bogor. p. 93-97.

Jauhari, R.Z. 1996. Studies on The Utilization of Fishmeal and Soybean Meal as Protein Source and Optimal Protein-Energy Supply in The Diet for Giant Gouramy (Osphronemus gouramy Lac.) and Tilapia (Oreochromis niloticus). PhD-Desertation. Fac. of Agric., Goerge-august Univ. Gottingen. 123 pp.

Kanazawa, A., Shimaya, M., Kawasahi, M., and Kashiwada, K. 1970. Nutritional requirements of prawn, I. feeding on artificial diet. Bull. Jpn. Soc. Sci. Fish. 36: 949-954

Kartikaningsih, H., Wiadya, D.G.R., Suryanti, Y., Subagyo, dan Hariati, A.M. 1997. Peranan chitin dari limbah pengolahan udang sebagai pemacu pertumbuhan ikan gouramy Osphronemus gouramy (Lac.) Laporan Hasil Penelitian ARMP-Il (belum dipublikasikan).

Kitabayashi, K., Kurata. H., Shudo, K., Nakamura, K., and Ishikawa, K. 1971. Studies on formula feed for kuruma prawn. I. On relationship among glucosamine, phosphorus and calcium. Bull. Tokai Reg. Fish. Res. Lab. 65: 91-207.

Kusdiarti, Subamia, I.W., dan Insan, I.W. 1995. Pembenihan ikan gurami di lahan tadah hujan dengan metode air resirkulasi dan penambahan komplek enzim pada pakan. Prosiding Seminar Hasil Penelitian Perikanan Air Tawar 1993/1994. Balai Penelitian Perikanan Air Tawar, Sukamandi. p. 295300 .

NRC. 1993. Nutrient Requirement of Fish. National Academy Press, Washington D.C. 115 pp.

Putro, S. 1982. Studies on Degradation of Chitinoclastic Microorganism for Shrimp Waste Fermentation. PhD Disertation, Univ. Washington, USA. 135 pp.

Snedecor, G. dan Cochran, W. 1991. Statistical Methods. $8^{\text {th }}$ edition, lowa State University Press, lowa, USA. $499 \mathrm{pp}$.

Suhadi, Santoso, U., Angrahini, S., dan Nurcahyanto, 1993. Buku Monograf Khitin dan Khitosan. PAU. Pangan dan Gizi. UGM, Yogyakarta. 73 pp. 